\title{
Correlation between changes in mechanical strength and damping of a high alumina refractory castable progressively damaged by thermal shock
}

\author{
(Correlação entre alterações na resistência mecânica e no \\ amortecimento de um concreto refratário de alta alumina \\ com dano progressivo por choque térmico)
}

\author{
A. H. A. Pereira ${ }^{1}$, G. M. Fortes ${ }^{1}$, B. Schickle', T. Tonnesen' ${ }^{2}$ B. Musolino ${ }^{3}$, C. D. Maciel ${ }^{3}$, J. A. Rodrigues ${ }^{1}$ \\ ${ }^{\prime}$ Materials Microstructural Design Group - GEMM, Materials Engineering Department - DEMa, Federal \\ University of S. Carlos - UFSCar, Rod. Washington Luiz, km 235, S. Carlos, SP, Brazil 13565-905 \\ ${ }^{2}$ GHI/RWTH - Aachen, Aachen, Germany \\ ${ }^{3}$ Electrical Eng. Department, University of S. Paulo, S. Carlos, SP, Brazil \\ ha@atcp.com.br,josear@ufscar.br
}

\begin{abstract}
Resistance to thermal shock damage is an important characteristic in refractory materials, since it determines their performance and service life in many applications. Therefore, the use of more sensitive techniques is desirable to improve the evaluation of thermal shock damage and monitoring of nucleation and propagation cracks and microcracks. The aim of this work was to evaluate the potential of damping change characterization to quantify thermal shock damage and to estimate the retained mechanical strength in complement to the dynamic Young's modulus test. Variations in damping and retained Young's modulus and their correlation with the mechanical strength of a high alumina refractory castable were evaluated at different thermal shock temperatures and number of cycles. The changes in damping were proportional to the retained mechanical strength, similarly to the retained Young's modulus. Changes in damping were also detected which were not indicated by the Young's modulus measurements.

Keywords: damping, internal friction, mechanical strength, modulus of rupture, Young's modulus.
\end{abstract}

Resumo

A resistência ao dano por choque térmico é uma característica importante dos materiais refratários visto que determina o desempenho e vida útil destes materiais em várias aplicações. Portanto é desejável a aplicação de técnicas mais sensiveis para avaliação do dano por choque térmico e monitoração da nucleação e expansão de trincas e microtrincas. O objetivo deste trabalho foi avaliar o potencial da caracterização da variação do amortecimento para quantificar o dano por choque térmico e para estimar o módulo de ruptura retido, complementarmente à caracterização do módulo de Young dinâmico. Foram estudadas as variações do amortecimento, do módulo de Young retido e a correlação destas variações com a resistência mecânica de um concreto refratário de alta alumina para distintas variações de temperatura e número de ciclos. As alterações encontradas no amortecimento foram proporcionais à resistência mecânica retida de forma similar a ocorrida para o módulo de Young retido. Também foram detectadas alterações no amortecimento não registradas no módulo de Young.

Palavras-chave: amortecimento, atrito interno, resistência mecânica, módulo de ruptura, módulo de Young.

\section{INTRODUCTION}

The selection and development of refractory materials for thermal shock applications can be oriented basically into two directions. The preferential one is the selection of materials able to resist thermal shocks without fracture nucleation based on a low thermal expansion coefficient and elastic modulus and high mechanical strength and thermal conductivity. However, for highly demanding applications in which fracture nucleation is usually unavoidable, the second and more suitable approach is to select or develop a material able to withstand thermal shocks with the lowest possible degree of damage. This ability is determined primarily by low mechanical strength, high elastic modulus and high fracture energy. Particularly when the objective is to minimize the degree of damage, crack and microcrack nucleation, propagation and arrest are the main factors to optimize the material's thermal shock resistance $[1,2]$.

The most common way to evaluate thermal shock damage is to characterize mechanical strength and retained dynamic elastic modulus and, to a lesser extent, damping $[2,3]$. Damping quantifies the material's mechanical 
energy loss rate and is strongly correlated with friction in the walls of cracks and microcrack, and hence, with the crack's configuration, density and length $[3,4]$. For quality control and inspection, damping would be a practical alternative because it is an intensive variable whose measurement does not require knowledge of the material's other properties or the specimen's dimensions. However, it should be noted that the correlation of damping with the traditional thermal shock resistance parameters is not well known. The dynamic elastic modulus is proportional to the mechanical strength [5] and is simple to characterize; however, its calculation requires measuring the specimen's dimensions and weight.

Considering that decreased mechanical strength and retained elastic modulus are due to the occurrence of cracking and microcracking, and that changes in the material's damping are due to mechanical friction of the new crack and microcrack walls, it can be inferred that there should be a correlation between the changes in damping and mechanical strength.

\section{MATERIAL AND METHODS}

\section{Material}

The material was a commercial high alumina castable containing an alumina matrix (96.9\%) and electrofused alumina aggregates with sizes of up to $20 \mathrm{~mm}(3 \%)$. Anhydrous nitric acid $(0.1 \%)$ was used as a dispersion additive. Fifteen prismatic bars were prepared with dimensions of $25 \mathrm{~mm} \times 25 \mathrm{~mm} \times 150 \mathrm{~mm}$. The bars were calcined at $600{ }^{\circ} \mathrm{C}$, followed by sintering at $1200{ }^{\circ} \mathrm{C}$ for $12 \mathrm{~h}$. After firing, the upper surface of the specimens was ground.

\section{Thermal shock procedure}

The thermal shocks were applied in heating and cooling cycles with abrupt temperature changes varying from 650 to $850^{\circ} \mathrm{C}$. To apply the thermal shocks, the specimens at room temperature were placed rapidly in a muffle furnace at the predetermined temperature for $15 \mathrm{~min}$ and then removed to cool in air. The specimens were divided into 5 groups of 3 specimens each. Table I lists the temperature and maximum number of thermal shock cycles applied on each group.

Table I - Thermal shock parameters of the 5 groups of specimens.

[Tabela I - Parâmetros dos choques térmicos aplicados aos 5 grupos de amostras.]

\begin{tabular}{ccc}
\hline Groups & $\Delta \mathrm{T}\left({ }^{\circ} \mathrm{C}\right)$ & N. of Cycles \\
\hline A & 650 & 15 \\
B & 700 & 12 \\
C & 750 & 9 \\
D & 800 & 6 \\
E & 850 & 3 \\
\hline
\end{tabular}

\section{Characterization of Young's modulus}

The equipment used (Scanelastic, ATCP Physical Eng. Ltda., Brazil) was developed jointly by the GEMM group and an UFSCar high tech spin-off company. The Young's modulus was characterized non-destructively after each thermal shock cycle. The sonic resonance technique was applied according to the ASTM E 1875-00 standard [6]. As reference, each group of specimens was characterized before any thermal shock. This technique involves exciting the specimen's natural resonance frequencies and capturing them by wide frequ ency scanning through piezoelectric transducers. The sample holder applies the required mechanical boundary conditions, as indicated in Fig. 1. The elastic modulus was calculated from the resulting vibration spectrum using the Piquet equations that correlate the natural vibration frequencies, the specimen's dimensions and Young's modulus [7].

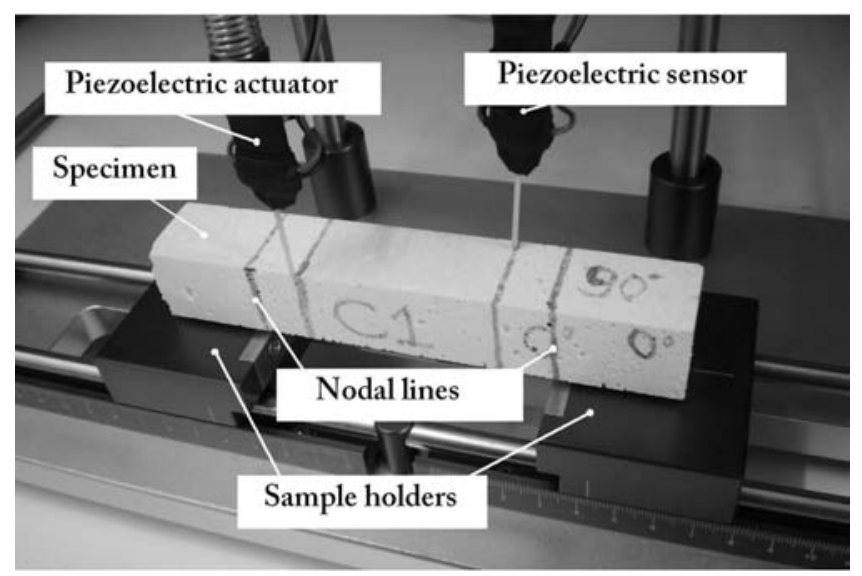

Figure 1: Sample holder used in the measurement of Young's modulus.

[Figura 1: Suporte de amostras utilizado na medição do modulo de Young.]

\section{Characterization of damping}

Damping was also characterized non-destructively, following the same schedule as the one used for the elastic moduli measurements. In this case, the impulse-response technique improved with time-frequency analysis was applied in association with the Levenberg-Marquardt algorithm optimized for noisy environments $[8,9]$. The impulse-response technique involves exciting the specimen's natural resonance frequencies with an impulse exciter while the specimen is supported by the sample holder under nodal lines, as illustrated in Fig. 2. The impulse exciter has a magnetic exciter whose impinges on the lower face of the specimen. The damping ratio is calculated from the amplitude decay of the specific frequency component corresponding to the resonant mode imposed by the sample holder's boundary conditions. This resonance is usually in the fundamental flexural mode. The Sonelastic device used for the modal frequency and damping analysis was also developed by the aforementioned spin-off company. 


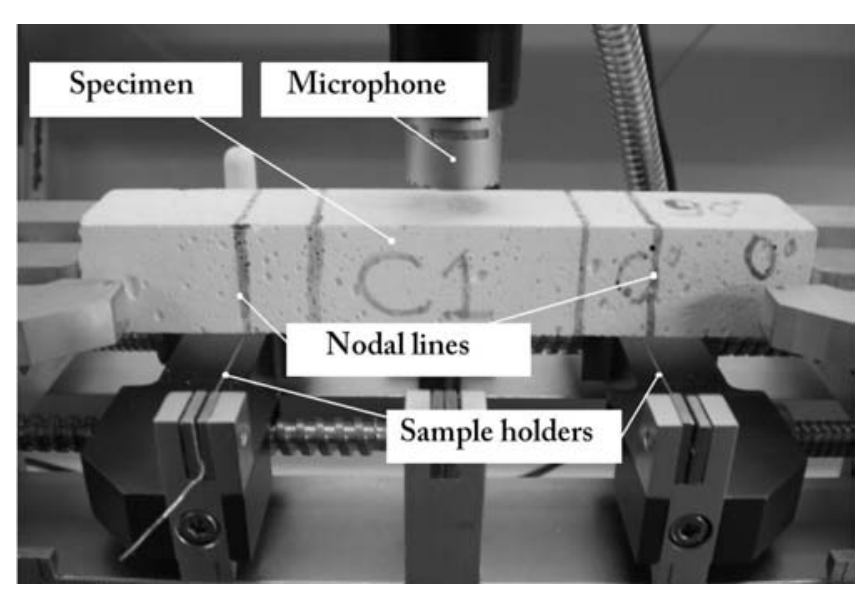

Figure 2: Sample holder used in the damping measurement.

[Figura 2: Suporte de amostra utilizado na medida do amortecimento.]

\section{Characterization of mechanical strength}

The mechanical strength was measured by the threepoint bending test (MTS 810, TestStar-IIs, MTS Systems Corp., USA), according to the DIN EN 993-6 standard, with a distance of $125 \mathrm{~mm}$ between the supports. The tests were carried out under a controlled load of $0.15 \mathrm{MPa} / \mathrm{s}$.

\section{RESULTS AND DISCUSSION}

The results obtained for the retained Young's modulus are presented in Fig. 3. The Young's modulus values show a significant decrease in the initial thermal shock cycles for all specimens and temperature variations. This decrease was proportional to the temperature change in every case. However, Young's modulus became almost stable as the number of cycles increased for thermal shocks with temperature variations equal to or below $750{ }^{\circ} \mathrm{C}$, indicating that such temperature variations are not sufficiently severe to cause additional damage.

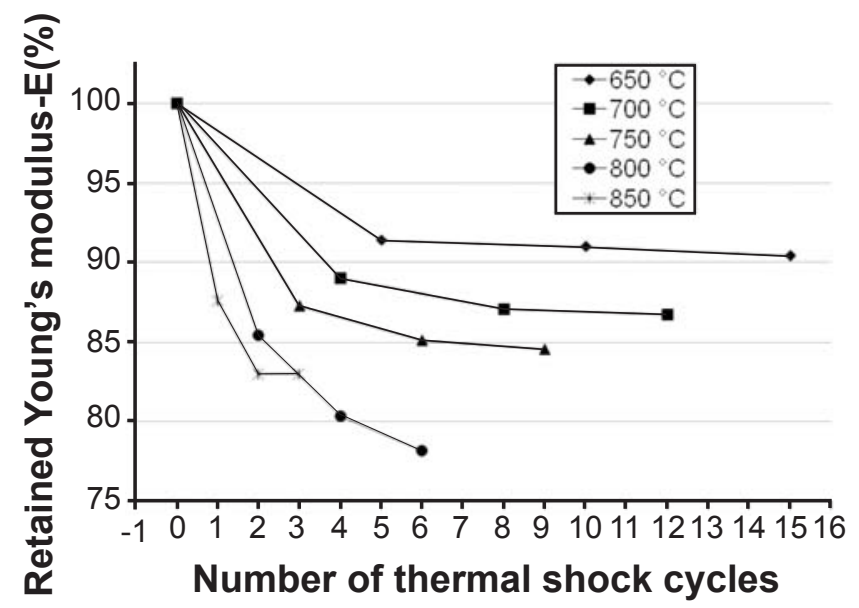

Figure 3: Retained Young's modulus, in percentage, after thermal shock cycles. The lines are simply visual guides.

[Figura 3: Módulo de Young retido percentual após ciclos de choque térmico. As linhas são apenas guias visuais.]
Fig. 4 shows the results obtained for the normalized damping changes. A monotonic increase in damping was expected as Young's modulus decreased in similar proportions due to both crack and microcrack nucleation and expansion. This is what the experiments show for the thermal shocks with temperature variations above 800 ${ }^{\circ} \mathrm{C}$. However, in the range of temperatures below or up to $750{ }^{\circ} \mathrm{C}$, an anomalous behavior was observed with a local maximum around the $3^{\text {rd }}$ to the $10^{\text {th }}$ thermal shock cycle, depending on the value of the temperature variation. This behavior may be associated with different stages of crack and microcrack expansion and stress relaxation, which affect the contact and friction between the cracks' walls or with other parameters not considered here, e.g., humidity, to which Young's modulus is not as sensitive as damping. This behavior has also been reported by researchers studying similar compositions of high alumina castables [10].

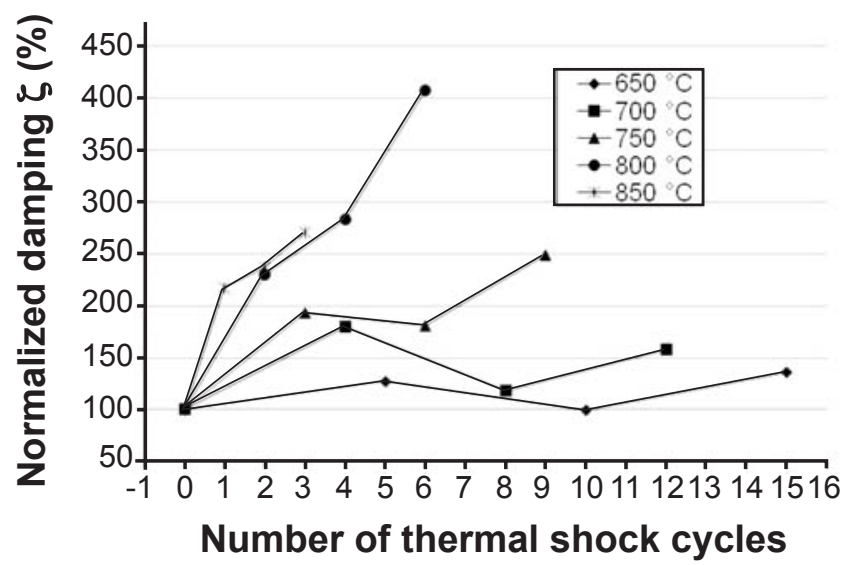

Figure 4: Normalized damping after thermal shock cycles. The lines are simply visual guides.

[Figura 4: Amortecimento normalizado após choques térmicos. As linhas são apenas guias visuais.]

The results obtained for the mechanical strength (3-point modulus of rupture) plotted against the retained Young's modulus and damping changes are presented in Figs. 5 and 6, respectively. Each measurement was carried out on 3 specimens to obtain average values for each of the 5 groups of specimens. The reference values for calculating $E(\%)$ and $\zeta(\%)$ were the those measured before applying any thermal shock on each group. The dotted lines in these figures are linear fits of the experimental points.

As described in the literature, the retained Young's modulus is proportional to the mechanical strength [5]. The maximum variation of retained Young's Modulus was $22 \%$ for the 6 thermal shock cycles applied at a temperature of $800{ }^{\circ} \mathrm{C}$. What is new in our results is that the damping change is also proportional (inversely) to the module of rupture, showing a higher sensitivity than the dynamic Young's modulus. The maximum damping change was more than $400 \%$ or 20 times greater than the maximum change in retained Young's modulus. 


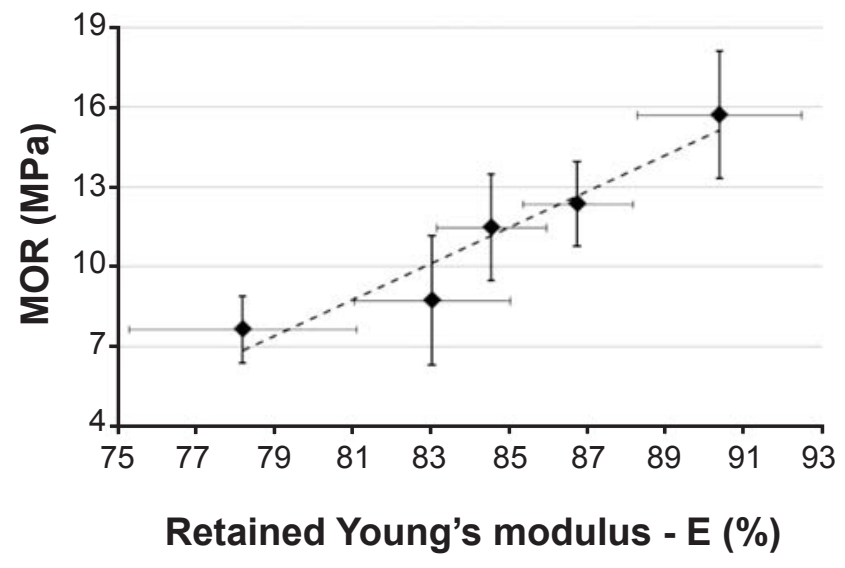

Figure 5: Modulus of rupture versus retained Young's modulus after thermal shocks. The dashed line is a linear fit.

[Figura 5: Módulo de ruptura versus o módulo de Young retido percentual. A linha pontilhada é um ajuste linear.]

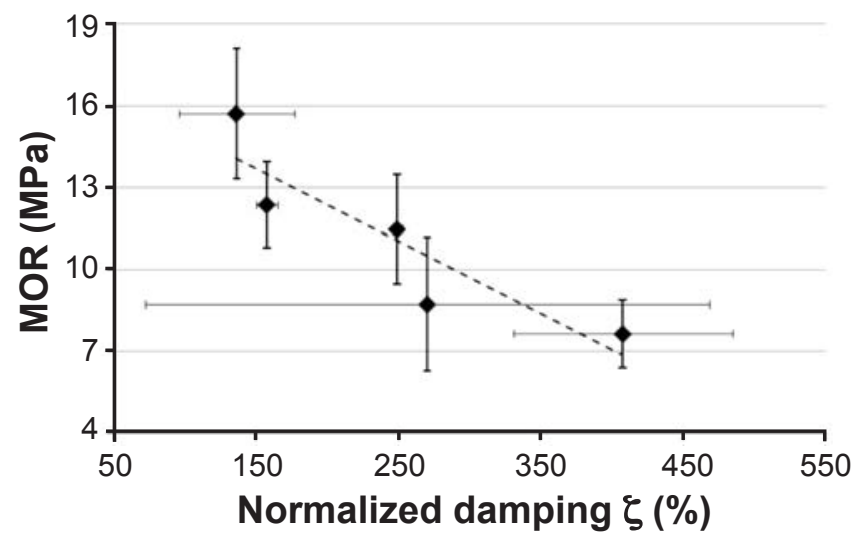

Figure 6: Modulus of rupture versus damping after thermal shocks. The dashed line is a linear fit.

[Figura 6: Módulo de ruptura versus amortecimento percentual. A linha pontilhada é um ajuste linear.]

\section{CONCLUSIONS}

This work shows that there is a direct association between changes in damping and mechanical strength due to thermal shock damage in the high alumina castable of this study. With additional work, this direct association can enable damping measurements to become a complementary alternative to improve the evaluation of thermal shock damage. This paper also shows that some microstructural changes or the influence of other parameters are identified by damping measurements and not by changes in the dynamic elastic modulus. Depending on the thermal shock parameters, the damping values display anomalous behavior, e.g., a local maximum. Further experiments are being designed to investigate the correlation of this anomalous behavior and the mechanical strength and other parameters involved, including relative humidity.

\section{ACKNOWLEDGEMENTS}

The authors acknowledge the financial support of the Brazilian agencies CNPq (Procs. 301073/2006-6 and 141868/2008-2), CAPES (PROBRAL Proj. 258/07 and BEX 3926/08-7), and FINEP (Proj. 4028-6) and of the German institution DAAD (Deutscher Akademischer Austausch Dienst).

\section{REFERENCES}

[1] D. P. Hasselman, J. Am. Ceram. Soc. 46, 11 (1963) 535.

[2] W. D. Kingery, J. Am. Ceram. Soc. 38, 3 (1955) 3.

[3] J. A. Coppola, J. Am. Ceram. Soc. 56, 4 (1973) 214.

[4] M. Ortiz, Mechanics of Materials 4, 1 (1985) 67.

[5] A. Fawzy, C. E. Semler, Am. Ceram. Soc. Bull. 64, 12 (1985) 1555.

[6] American Society for Testing and Materials, ASTM E 1875, Dynamic Young's Modulus, Shear Modulus, and Poisson's Ratio by Sonic Resonance (2000).

[7] G. Pickett, Proc. ASTM 45 (1945) 846.

[8] L. Finschi, Technical Report, Institute for Operations Research, ETH Zürich (1996). http://www.ifor.math.ethz. ch/staff/finschi/LevMar/LevMar.pdf

[9] M. Karjalainen, P. Antsalo, A. Mäkivirta, T. Peltonen, V. Välimäki, J. Audio Eng. Soc. 50, 11 (2002) 867.

[10] T. Tonnesen, R. Telle, Ceram. Forum Int. 84, 9 (2007) E132.

(Rec. 28/01/2010, Ac. 20/02/2010) 